relevant in Africa. So must be adverse intrauterine environment, given that antenatal care is poor or absent in most parts of the continent. People often have multiple risk factors, as shown in a recent publication from South Africa which reported that $32.1 \%$ of men and $18.9 \%$ of women over 30 had a $20 \%$ or higher likelihood of developing cardiovascular disease in the next 10 years. ${ }^{4}$

Barriers to planning and providing care for people with cardiovascular disease compound the problem. For example, inadequate classification of deaths from cardiovascular disease in South Africa and of differences in patterns of risk and disease among ethnic groups hampered effective planning. ${ }^{5}$ Providers of primary and secondary health care in Nigeria reported barriers to managing cardiovascular risk which included inadequate financing, low competence among health workers, and poor laboratory support. ${ }^{6}$ And another study in Gambia found that poor recording of demographic data hindered the smooth execution of a project for people with cardiovascular disease. ${ }^{7}$ Furthermore, and unsurprisingly, Africa has the lowest output in the world of cardiovascular research. $^{8}$

There is hope though, and some attention has finally been focused on cardiovascular disease in Africa. The International Forum for Hypertension Control and Prevention in Africa published clinical management guidelines for the whole continent in $2003 .^{9}$ National initiatives to identify risk factors and set guidelines are now under way. Some countries have carried out national epidemiological surveys, a few have begun to continually monitor and assess their programmes, and some countries, South Africa and Nigeria among them, have their own guidelines for managing hypertension.

Such national and local strategies are essential, not least because measures imported wholesale from developed countries may not always be directly applicable locally. Health authorities and doctors know what they need to do to tackle cardiovascular disease. But difficulties such as underfunding, poor infrastructure, inadequate access to cheap generic drugs and fixed dose combinations, and lack of public recognition and acceptance of the importance of cardiovascular disease will continue to hinder the effective implementation of both population based health programmes and those aimed at people at high risk. The continent's people need education on healthier (but, perhaps in some African societies, culturally undesirable) lifestyles such as weight reduction, smoking cessation, and greater physical activity.

\section{S Kadiri consultant physician}

Department of Medicine, University College Hospital, Ibadan, Nigeria (skadiri@skannet.com)

Competing interests: None declared.

1 World Health Organization. World health report 2002. Reducing risks, promoting healthy life. Geneva: WHO, 2002. www.who.int/whr/2002/en promoting healthy life. Geneva: WHO,

2 Reddy KS, Yusuf S. Emerging epidemic of cardiovascular disease in developing countries. Circulation 1998;97:596-601.

3 Cooper RS, Rotimi CN, Kaufman JS, Muna WFT, Mensah GA. Hypertension treatment and control in sub-Saharan Africa: the epidemiologic basis for policy. BMJ 1998; 16:614-7.

4 Alberts M, Urdal P, Steyn K, Stensvold I, Tverdal A, Nel JH et al. Prevalence of cardiovascular diseases and associated risk factors in a rural black population of South Africa. Eur I Cardiovasc Prev Rehabil 2.947-354.

5 Bradshaw D. What do we know about the burden of cardiovascular disease in South Africa? Cardiovasc J South Afr 2005;16:140-1.

6 Mendis S, Abegunde D, Oladapo O, Celleti F, Nordet P. Barriers to management of cardiovascular risk in a low-resource setting using hypertension as an entry point. J Hypertens 2004;22:59-64.

Kobal SL, Czer LSC, Czer P, Feldsher Z, Hamilton R, Siegel RJ. Making an impossible mission possible. Chest 2004;125:293-6.

8 Rosmarakis ES, Vergidis PI, Soteriades ES, Paraschakis K, Papastamataki $\mathrm{PA}$, Falagas ME Estimates of global production in cardiovascular diseases research Int J Cardiol 2005; 100:443-9.

9 Lemogoum D, Seedat YK, Mabadeje AF, Mendis S, Bovet P, Onwubere B, et al; International Forum for Hypertension control and prevention in Africa. Recommendations for prevention, diagnosis and management of hypertension and cardiovascular risk factors in sub-Saharan Africa. $J$ Hypertens 2003;21:1993-2000.

\title{
BMA and BMJ Information Fund
}

The British Medical Association and the $B M J$ have established a small fund to enable us to respond to requests for health information from organisations in developing countries and other areas of need.

The fund does not grant money; rather, it provides educational materials such as books, journals, CD Roms, and DVDs. In the case of organisations with internet facilities, we may be able to provide access to online journals. We are unable to accept applications from individuals but are pleased to consider applications from, or on behalf of, medical schools, medical libraries, healthcare institutions and related organisations, including non-governmental organisations.

The closing date for 2005 applications is Friday 11 November 2005.

For more information and to make an application go to www.bma.org.uk/infofund. 